\title{
Technology-based Participatory Learning for Indigenous Children in Chiapas Schools, Mexico
}

\author{
Yolanda Heredia, Universidad TecVirtual, and \\ Jose I. Icaza, Campus Monterey, \\ Sistema Tecnológico de Monterrey, Monterrey, México
}

\author{
yheredia@tecvirtual.mx jicaza@itesm.mx
}

\section{Executive Summary}

This research created a technology-based learning environment at two schools belonging to the National Council of Educational Development (CONAFE) for indigenous children in the state of Chiapas, Mexico. The purpose of the study was to describe the educational impact of using the Classmate PC netbooks and the Sugar Educational Platform in the pedagogical practice of community instructors (teachers) and in the development of technological and cognitive skills in students on third and fourth grades of elementary school.

All students and instructors were given computers; the three community instructors were trained in the use of the technology and in the constructionist pedagogical model. It was necessary to provide an electrical charging station for the computers in the classroom; the battery was charged overnight using a timer and then lasted for the whole school morning.

The researchers visited the two one-room schools six times during a whole school year in order to register classroom observations, conduct interviews, and gather electronic portfolios of the students; these are automatically kept by the Sugar platform.

One of the findings of the research was that there was a positive impact on the development of both technological and cognitive skills as the students increased the mastery of the Sugar educational activities. Another finding is that the mouse pad is a better tool for children than the mouse because the students had had little contact with computer equipment before.

Sugar activities freely chosen by the students on their free time included recording photos and videos, doing puzzles, playing memory games, and Paint; the ones most used in academic activities were Write, Talking To Sara (a Spanish chat bot), Story Writer, and Calculator.

The mastery of the computers and activities enhanced self-confidence of the children and increased their Spanish linguistic abilities (their native language is Tzotzil)

The community instructors enriched their teaching by incorporating on a systematic and daily basis the computer and Sugar activities.

Material published as part of this publication, either on-line or in print, is copyrighted by the Informing Science Institute. Permission to make digital or paper copy of part or all of these works for personal or classroom use is granted without fee provided that the copies are not made or distributed for profit or commercial advantage AND that copies 1) bear this notice in full and 2) give the full citation on the first page. It is permissible to abstract these works so long as credit is given. To copy in all other cases or to republish or to post on a server or to redistribute to lists requires specific permission and payment of a fee. Contact Publisher@,InformingScience.org to request redistribution permission.
Further, they incorporated both individual and collaborative activities with the computer to strengthen the thematic content of the curriculum. In a similar way to the students, instructors also increased their confidence with the technology and in their teaching abilities. 
Finally, the study can state that the combination of Classmate and Sugar is an effective learning environment based on technology in this impoverished environment.

Key words: Technology-based learning, participatory learning, indigenous children, constructionism, teacher practice, technological and cognitive skills, ICT4D

\section{Introduction}

All children should have the opportunity to develop the skills and competencies needed in the XXI century regardless of social and economic conditions. Important amongst these abilities are technological abilities, particularly those that may facilitate the development of reading, writing, and cognitive skills.

In an economically deprived environment, such as Chiapas in Mexico, students lack educational environments enriched with technology; further, they have the lowest educational achievement in Mexico (Secretaría de Educación Pública, 2012; Secretaría de Hacienda y Credito Público, 2010). Professors of rural schools are young people who have finished high school, but lack pedagogical frameworks in general, and know little about the use of technology in education. The youngest children in these Chiapas Schools speak only an indigenous language, Tzotzil, which makes it more difficult for them to achieve academically.

To cope with this situation, this study's main objective was to design, develop, and implement a technology-based educational model to enhance the quality of learning in elementary school students in Chiapas' rural schools. This included training instructors in developing lesson plans based on technology and its use in the classroom and in gathering evidence to show that technology-based educational models can be successfully implemented in rural indigenous environments. The research took place during a full school year, from August 2009 to May 2010.

The researchers initially took the participatory learning definition of Davidson, that "includes the ways in which new technologies enable learners (of any age) to contribute in diverse ways to individual and shared learning goals" (Davidson, cited in Bass \& Schlafly, 2009, p. 1). This approach is compatible with the constructionist (different from constructivism) educational model (Papert \& Harel, 1991).

Our main strategy was to provide the instructors with the constructionist model that included the use of one-to-one netbooks incorporating the Sugar Learning Environment (SugarLabs, 2009a, 2009b, 2009c, 2009d, 2009e), derived from the One Laptop Per Child (OLPC) MIT project (One Laptop Per Child [OLPC], 2008). We trained instructors and children in the educational model and the use of the technology and observed the evolving results during a whole school year with interviews and direct observation of the lessons. We gradually witnessed the impact of this technology-rich environment on the development of the student's cognitive abilities and the instructors' teaching abilities.

\section{Background}

\section{About Chiapas}

The state of Chiapas is one of the 31 states of Mexico and is located in the south-east part of the country. Chiapas is known for its rich colorful culture, its great natural resources, and a diverse and magical cultural heritage. Unfortunately, it is also characterized by extreme poverty.

Based on data collected in 2010, the state's population is the eighth largest in Mexico, with 4,796,580 people, distributed mainly among 19,386 small mountain towns; 14,346 of which have less than 100 inhabitants (Secretaría de Hacienda y Crédito Público, 2010). 
Chiapas is home to more than 957,000 people who speak an indigenous language. This is about $22 \%$ of the state's population (Instituto Nacional de Estadística y Geografía, 2012). Since Spanish is the country's official language, not speaking Spanish is a limiting factor for the indigenous population who need to access information and school knowledge; obtain administrative services outside of their community, as well as solve legal disputes (Coronel, 2008). Educational backwardness is also a feature of the state. Children and young people leave school early, and school performance is the lowest in the country when measured by national standardized tests (Secretaría de Educación Pública, 2012; Sistema Estatal de Información Estadística y Geográfica de Chiapas, 2007).

The Tzotzil is one of Mexico's indigenous groups whose language belongs to the Mayan family. People in this group are mainly concentrated in the area known as Los Altos de Chiapas. They live in small valleys and mountains located near the city of San Cristobal de las Casas. Their religion is a curious mixture of Catholicism and ancient customs; in particular, they have strong allegiance to Christian Saints, perhaps as a modern reflection of ancient adoration of indigenous idols. Villages are often attached to different Saints, and they periodically organize large celebrations to honor their respective saints. Lately, the Protestants religion has taken root in some villages, causing some religious conflict. Their economy is based on agriculture and lamb husbandry and the production of handcrafts, particularly rich wool textiles (Obregon, 2003).

\section{The National Council for Educational Development}

The differentiated educational services offered to geographically dispersed communities with few students, many of whom speak indigenous languages, are the responsibility of the National Council of Educational Development (Consejo Nacional de Fomento Educativo - CONAFE), a public agency created by presidential decree in 1971. Its educational model considers the social and cultural diversity of these groups, as well as their economic disadvantage. The ultimate aim is to expand opportunities for access, retention, and educational attainment of children living in rural areas, indigenous people, migrants, and the impoverished people in the country (Consejo Nacional de Fomento Educativo [CONAFE], 2009). This model includes learning Spanish as a second language.

The CONAFE educational model has some special features (Torres \& Tenti, 2000) such as:

- Consideration of the infrastructure of the vast majority of rural schools, which is generally poor

- Curriculum adapted to rural and indigenous areas

- The teacher is a young adult culturally close to the community, whose level of schooling may be junior high or high school, with just emerging pedagogical training offered almost on the fly

- Generally the school is multi-graded, where pupils of different ages and skill levels are assisted by one instructor in the same classroom

Within the strategic objectives of CONAFE (2007), this institution identifies priority groups, including indigenous people and communities. The aim is to fully incorporate these groups to the economic, social, and cultural development of the country while respecting their traditions and enriching the rest of society with their cultural heritage. The strategy is to guide actions and create programs to reduce the backwardness in education, health, and nutrition.

Modalidad de Atencion Educativa a Población Indígena (Educational Attention Modality for Indigenous People) (MAEPI) of CONAFE is the result of these specific actions. The strategic purpose of Indigenous community's education in the context of CONAFE is: 
Transforming the school within small indigenous groups, into a community space in which subjects can re-create and develop their language and culture in terms of their basic needs, while promoting useful and meaningful exchanges with other customs, knowledge and beliefs that have both similar cultures as well as distant and different ones, including modern technologies, to achieve improvement in their conditions and quality of life. (CONAFE, 2006, p. 21)

\section{Technology-based Learning Environments}

With the advances of technology, in the international context there has been a search for and the development of increasingly complex and diversified learning environments based on technology, using mobile rather than fixed devices, and an increased proliferation of interactive and virtual reality educational games and recreational materials for students and teachers at all educational levels (Coll \& Monereo, 2008).

The learning environments, based on technology that has been tried in educational institutions worldwide, can be classified by the way teachers and students meet and interact. The diversity of environments can be modeled as a continuum that has two extremes: on one hand we have the traditional face to face classroom learning environments without technology, and on the other extreme the online learning environment (e-learning). The midpoint is represented by the hybrid environment (blended learning) (See Figure 1)

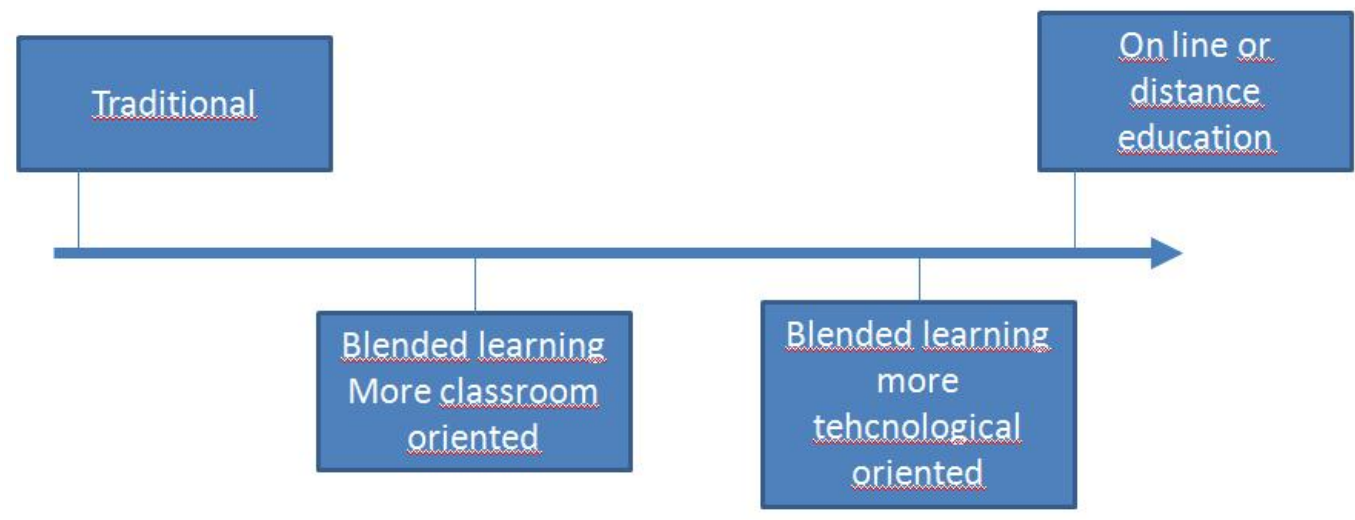

Figure 1-Learning environments based on technology (Cantú \& Heredia, 2010)

Traditional learning environments are those in which instruction is given face to face. In general, teachers either do not use or make very limited use of technology in the classroom, and their teaching method is mainly expository.

Hybrid learning environments (blended learning) are those that combine elements of classroom instruction with electronic elements to allow extending the classroom beyond the school boundaries (Osguthorpe \& Graham, 2003, p. 229; Kerr \& Witt, 2003, p. 101 both cited in Mortera, 2008, p. 129). In these scenarios, the teacher has more or less limited technological resources, which can be used, for instance, as a repository of teaching materials. Another form of this combined environment is one that occurs when students have mobile computing devices that they use more or less intensively in or out of the classroom for individual activities or group learning led by the teacher. 
This study was conducted in a blended-learning environment in which the face-to-face class was enriched with the use of technology; further, as the netbooks are very light, the kids used them to complete out-of-class activities under the guidance of the instructor.

\section{Learning One-to-one}

One form of blended learning is a model called One to One (One-to-One Learning, One-to-OneMobile Computing, One-to-One Initiatives) (Penuel, 2004). While definitions vary in the literature, the initiative of Learning One-to-One basically describes a teaching and learning environment where every teacher and every student has a laptop or netbook for continual use at school or at home. Although each student has his/her own computer, collaboration among students is encouraged through a wireless computer network that links up the machines. According to Alberta Education $(2006,2009)$, the conditions needed for this environment to be successful are (1) mobile computing equipment, preferably including Internet accessibility, (2) software and multimedia learning resources, (3) a collaborative learning environment, (4) teachers trained in the use of the computers and its application in the classroom, and (5) lesson plans that include the computer as a resource.

For this project, the researchers furnished the classrooms with netbook computers for each student and instructor, electrical and network connections, and a made-to-order charging station. It was not possible to obtain Internet access due to the geographical location of the schools.

Netbooks included the Sugar learning environment and multimedia resources. We arranged for network connections so that the children could share the results of their activities with other children and the instructor inside the classroom. The researchers conducted training sessions for instructors and the students on the use of the technology and the educational model and developed initial lesson plans to serve as examples; the instructors then developed their own plans.

\section{Constructionism}

Another aspect of utmost importance for enabling environments for technology-based learning is the way people conceive of learning. Since knowledge is not transmitted but built up by the students, education is essentially providing opportunities for learners to engage in activities that promote this constructive process, which has been called constructivism.

Constructionism derives from constructivism; it has the same educational philosophy related to learners actively constructing rather than receiving knowledge. This view of learning is reflected in the educational approach of MIT researcher Seymour Papert on the use of computers as learning tools (Badilla \& Chacon, 2004; Papert, 1993; Papert \& Harel, 1991). In the early sixties, at the beginning of the computer age, Papert noted the difficulty that children had in using the machines because they had to use programming languages that were very complicated. This observation led him to take two important decisions: to study with Jean Piaget about his epistemological theory, and to collaborate with Marvin Minsky, the theorist of artificial intelligence. That was the starting point of constructionism.

The theory of constructionism states that learning is greatly benefited if the student engages in the construction of a significant product, which can be anything from a text, a drawing, craft, a computer program or a simple machine. Papert, through his constructionist approach, gives learners an active role as designers of their own projects to build up their own learning (Falbel, 2001). He designed the Logo language, which through the metaphor of a turtle that draws when following orders given by the children, facilitated the construction of geometric figures and the learning of geometry and mathematics. Logo was later extended to incorporate all the features of a complete yet simple programming language. Subsequently, other languages and software products have been designed to facilitate this process of construction of various digital objects (MicroWorlds, 
Crazy Machines and several of the Sugar Learning Activities (SugarLabs, 2010) among many others).

Our constructionist approach included these five basic steps:

a) The instructor generated a learning situation based on the curriculum, usually regarding the use of language, math or science.

b) To solve this situation, the students often collaborated in small teams about how to approach the learning situation.

c) The students built some objects that represent their approach, often using one of the Sugar learning activities; this could be a drawing, animation, report, picture, computer program, and so on.

d) The students shared their solution with each other through the computer network and requested feedback from other students or the instructor. Sugar also allowed students to collaborate simultaneously in the construction of the digital object by sharing their screens.

e) The students improved their constructed objects taking this feedback into account (Icaza, 2008).

The researchers expected this constructionist educational model, combined with the mobile netbooks and the Sugar learning environment, to enhance the development of children's cognitive abilities and the instructor's educational abilities and practice. The researchers expected these abilities to be useful to everyone in order to confront the changing world that they will be facing in the future.

\section{Related Research}

When this study commenced, there were no articles regarding the use of one-to-one netbooks using the Sugar Learning Environment in rural schools. Since then, the researchers have found results regarding the use of the OLPC and Sugar in Uruguay (Hourcade, Beitler, Cormenzana, \& Flores, 2008). The research reports a pilot experience in a rural town close to the city of Montevideo. The school there had 150 students and received XO laptops (actually netbooks) donated by the OLPC foundation. The results show a very positive and transformative impact in the way that the children learn, in spite of serious hardware and infrastructure problems. Student enthusiasm was evident, especially because students shared new findings such as recently found web computer games with other students. There was no special pedagogical training so that teachers could match curriculum requirements with the use of technology.

Based on this success, the Uruguayan government implemented the CEIBAL project, to provide every primary-school child in public elementary schools with an XO netbook. As a result, 350,000 computers were distributed. After one year, teachers reported that the most common activity was the use of the web, and that this had motivated the children to read more and find interesting content. The students also uploaded videos to the web; the second most frequent activity included the use of the text editor, the drawing program, the camera and TurtleArt, a graphical programming language (Flores \& Hourcade, 2009)

Another important technology initiative was the OLPC netbook program in Peru, started in 2007 in 559 rural schools (Santiago, Severin, Cristia, Ibarraran, Thompson, \& Cueto, 2010). The program gave a computer to every student and teacher. Teachers received basic training and user's manuals on the use of the technology. The authors evaluated this experience using qualitative and quantitative methods. They found that in 4 out of 6 schools studied, some computers were never used or taken home, as families feared computers might be damaged or stolen. Students explored their netbooks spontaneously and discovered several activities that were not explicitly taught by their teachers. Teachers said that the training they received was not sufficient; however teachers 
that received netbooks were more satisfied with their work than those of the control schools. Parents were also more satisfied with the school.

Despite student enthusiasm, there were no significant differences between academic results of students with or without netbooks.

An unsuccessful case was reported in the OLPC program of Birmingham, Alabama (Warschauer, Cotton, \& Ames, 2011). A top-down decision was made to distribute 15,000 netbooks to poor children in grades 1-5 without consulting either teachers or the schools. Not surprisingly, teachers did not show much interest in using the netbooks during class time. The children did not use the netbooks much either for fear of damaging them. The program was later canceled.

Finally, the researchers found a further study in Mexican middle-class urban schools, both private and public (Cervantes, Warschauer, Nardi, \& Sambasivan, 2011). A total of 128 hours of in-class observation took place to describe the role of the netbooks in teaching and learning activities. Low-income students had the opportunity to have their own computer under teacher supervision. In these schools, teacher training and techno-pedagogical support were found to be crucial factors that allowed the teachers to use the netbooks as a learning resource and take more risks to incorporate multi-media resources. These students, as in several other reports, enjoyed having their own computer and showed more interest in school activities.

\section{Methodology}

\section{Research Objectives}

1. To create a constructionist educational environment based on one-on-one netbooks and the Sugar Learning Platform

2. To observe the year long impact of this environment on the development of student's cognitive abilities and on the teacher's teaching abilities and practice.

\section{Research Design}

This qualitative study examines three important aspects of creating a learning environment based on technology in the form of One to One Learning with the educational philosophy of constructionism: the implementation of a learning environment based on technology, the impact on the students' thinking skills and the community instructors' teaching practice.

\section{The Schools}

Two elementary schools were selected with the help of the CONAFE's regional authorities. One school is located in the Tilil community at Chamula municipality and the other in the community of Naxoch II at the municipality of Larrainzar. Both schools had access to electricity; this is true for about half of the schools in rural Chiapas. The schools are respectively 35 and $70 \mathrm{~km}$ away from the city of San Cristobal. In each of the schools, the researchers worked with the community instructors and their students on the second level of the CONAFE program, the equivalent of the third and fourth grade of primary school. The two schools have multi-graded classrooms: one single classroom for children attending first to third grade, another one for children attending fourth to sixth grade, and one more for junior high students. Each school had about 30 students in total. 


\section{Participants}

The participants were 24 indigenous Tzotzil students, who were speakers of their native language and attending the third and fourth grade of elementary school:

- Their age range was 7-12 years.

- There were $49 \%$ boys and $51 \%$ girls.

- $78 \%$ attended preschool

- $55 \%$ could maintain a simple conversation in Spanish but $40 \%$ couldn't read or write it well

- $90 \%$ of students worked at home to support their parents in daily household chores and home-based agriculture, and they all did school homework when requested.

- $40 \%$ of the students' mothers had an incomplete elementary schooling; $20 \%$ completed primary school and the rest did not know.

- In the case of fathers, $60 \%$ received complete primary education.

- All families were functional and made up of parents and children.

- At home, children received little or no support with their homework.

The other participants in this study were the community instructors. The Tilil community classroom had two female community instructors; the classroom at Naxoch had one male instructor.

- All three were single

- Age range: 19 to 20 year old,

- Speakers of Tzotzil and Spanish

- They had finished high school

- They were in their first year of community teaching service. (Instructors typically work at their assigned school for one or two years only, and then CONAFE grants them a scholarship for undergraduate studies)

- The three instructors had basic notions about how to use a computer for simple tasks such as chatting;

- They did not have formal training in pedagogy.

\section{Hardware and Software}

\section{Description of computer equipment}

The researchers selected Classmate convertible netbooks, made especially for children. This equipment has a screen that can rotate vertically 180 degrees. It has a touch screen; however the Sugar software did not support this kind of screen, so this feature was not used. The Classmate has a photographic camera that can rotate horizontally 180 degrees and is able to take both photos and video. It has a fast processor and $1 \mathrm{~Gb}$ of memory, USB, SD ports and wireless capability. The 60GB hard disk was not used either because all the children's work was stored in the Sugar SD card.

\section{Charging station}

The researchers decided not to allow netbooks to be taken home, because the humid forest surrounding the schools contains lots of loose dirt that could damage the machines. So, in order to store the students' netbooks overnight and charge batteries, the researchers designed a charging station: a cabinet containing the computers and wires connected to the power supply. For energy savings, the researchers also installed a timer. This device was programmed so that it would provide two hours of charging time to all the machines simultaneously; this allowed use of the computers for about four hours the following day. 


\section{Software Description}

The software used in this project was Sugar (SugarLabs, 2010), a free and open-source operating system for children, which facilitated the management of the computer with age-appropriate concepts; e.g., instead of "running applications", children "do activities" such as the Write or Calculate activity, which is a natural concept for them. It has a journal that automatically stores the results of activities undertaken by the children and in which they can make their own annotations. Office concepts such as desktop, folders, or inboxes are absent. Instead, working with other children is extremely visible in the Sugar interface: just a "click" is needed to see the icons of other children in the classroom or friends, and another click to share the result, digital object or activity so that several children can collaborate on one screen in the construction of the digital object. The Sugar educational software applications are called activities. With these applications, the child learns, researches, shares, and reflects on the learning process. There are various activities that facilitate working with math and science, Spanish language, music composition, computer programming languages using simple graphic languages, constructing animations, etc. and other common ones such as writing, arithmetic, reading, browsing.

Sugar activities include E-toys, Scratch and Turtle-art for graphic programming, Tam Tam for composing music, Write for writing, Record to record photographs, videos, or sound, puzzles, calculators, memory, physics, Talking to Sara (Spanish language, chats), Story builder, and many others. All Sugar software activities are free and new activities are being developed all the time. Activities can be downloaded from Sugar Labs and run only on Sugar.

Sugar is currently (June 2012) used by two and a half million children around the world. It is available in 25 languages in over 40 countries as part of One Laptop per Child project at MIT. That project uses another type of computer, the XO-1, with characteristics similar to the Classmate, but both the XO-1 and the Classmate or actually any computer can run the same Sugar software.

Sugar was developed at the Media Lab of MIT. The Sugar version we used is called "Sugar On a Stick" and is stored on an SD card.

\section{Internet connection}

Both schools were equipped with $3 \mathrm{G}$ cellular modems, with unlimited internet access. Unfortunately, due to climatic and geographical conditions, the Internet signal within the classroom was very low, and sometimes lost, having a signal range from $5 \%$ to $10 \%$. The cell phone antennas were located, in the case of Tilil, no more than $10 \mathrm{~km}$ away from the school; but the mountainous area, extensive vegetation and $20 \mathrm{~cm}$ thick concrete blocks did not allow the signal to reach the school with the required strength. Similar conditions prevailed at Naxoch.

\section{Research Procedure}

The Sugar SD card was inserted to the Classmates and sent to the CONAFE offices in San Cristobal to be distributed to the communities. Schools were equipped with a modem for internet access, a server for each classroom running on another Classmate, the charging station mentioned previously, and special software developed by the research team to collect backups of the electronic portfolios ("Journals" in Sugar terminology) that Sugar automatically maintains on each machine.

Prior to the beginning of the school year there was an 8 hour training session for the community instructors so they could learn how to manage the equipment and software and how to use the constructionist approach. 
The research group designed 18 short lesson plans on Science, Mathematics, and the use and knowledge of the computer using some of the activities (applications) of Sugar so both pupils and community instructors could gradually take over the hardware and software. Each lesson plan was designed to last for about two to four hours of class time. The instructors initially used these pre-defined plans on whatever days they considered appropriate; later in the school year they started to design their own plans. The average time the computers were used during class time was about two hours per day.

Schools were visited six times (about every three weeks). Observations were made of class performance, the instructor, and the student interaction during the whole school day. Field notes were taken on all important events and personal observations. These registries included pictures and videos which can be seen at the project's website, https://sites.google.com/site/tecnotzotzil/Home

At each visit, the research group interviewed the instructors and some of the students using an interviewing guide. This guide included questions for the instructor related to the lesson plans used or designed, resources used, problems encountered and solutions, and a general overview of the impact of the pedagogical model and of the students' performance. The interview guide for the students included questions related to the use of the technology, what they liked the most, and whether they felt technology had made learning easier.

On each visit researchers obtained the journals (electronic portfolios) from the server backup in order to analyze the digital objects and learning outcomes during the project. This allowed the researchers to obtain quantitative data about the frequency of use of the netbooks, the number of times each Sugar learning activity had been used, the number of digital objects generated and copies of the digital objects produced by the children among others. They also obtained qualitative data about the outcomes of the technology-based lesson plans.

\section{Results}

The educational results can be divided into the impact on the students and the impact on the community instructors.

\section{Impact on Students}

At both schools, in the junior high classroom there was a computer prior to this research, so students knew the machines, but their direct contact with them was practically nil. In the primary classrooms where we carried on the research, children had not had any contact with computers. Once the elementary classrooms were equipped, the learning environment was enriched; however, this environment presented a challenge, as neither the students nor the instructors were familiar with the use of computers in the classroom.

At first, each student was equipped with a computer and mouse. But the great difficulties in mastering motor functions and the lack of space in school desks quickly became apparent, so the researchers opted to teach the use of the "touch pad" and this greatly facilitated the manipulation of the cursor. Curiously, many students spontaneously decided to use both hands at the touchpad, one for moving the cursor and the other for the "clicks".

The frequency of computer use in both schools was approximately two hours per day from August through May. It is to be noted that in this educational context there are frequent student absences due to traditional festivities, student illnesses, cold weather and the teachers' meetings at CONAFE offices in the city of San Cristobal. The average school year attendance is less than 200 days per school year. 
Table 1 relates some of the activities of Sugar with the abilities these activities help develop; however, not all of these activities were used with the same frequency:

Table 1. Sugar activities and skills developed

\begin{tabular}{|c|c|}
\hline Sugar Activities & Skills that children develop \\
\hline $\begin{array}{l}\text { E-toys, Scratch and } \\
\text { TortugArt }\end{array}$ & $\begin{array}{l}\text { Analysis, synthesis, creativity, organization, autonomy, } \\
\text { self-planning, computer programming skills, design skills }\end{array}$ \\
\hline Tortug-Art & $\begin{array}{l}\text { Geometrical and mathematical skills, production of com- } \\
\text { puter generated art, designing skills. }\end{array}$ \\
\hline Tam Tam & Synthesis, creativity, musical abilities, self-planning. \\
\hline Write & $\begin{array}{l}\text { Analysis, synthesis, creativity, organization, written com- } \\
\text { munication skills }\end{array}$ \\
\hline $\begin{array}{l}\text { Record (photographs, } \\
\text { video or audio) }\end{array}$ & Creativity, observation, communication abilities \\
\hline Puzzle & Spatial skills and pattern recognition \\
\hline Calculator & Arithmetical skills \\
\hline Memory game & $\begin{array}{l}\text { Spatial skills, memory skills; other skills depending on the } \\
\text { content on the board, which can be generated by the teach- } \\
\text { er }\end{array}$ \\
\hline Talking to Sara & Oral and written communication skills in Spanish \\
\hline Scratch and Etoys & $\begin{array}{l}\text { Design skills of new Sugar activities that can be used by } \\
\text { other children }\end{array}$ \\
\hline Paint & Graphic and artistic skills, spatial skills, design skills \\
\hline
\end{tabular}

In addition, all activities can promote participatory learning and collaboration because, as mentioned earlier, the results can be easily shared with other children through the computer network, and any activity can be shared in such a way that several kids can work on it at the same time, for instance, when composing a collaborative painting or document.

The research group also developed new Sugar activities for the children and made those available to the world through the Sugar Labs web site. New activities included "raining letters" to learn how to use the keyboard; "My world" that depicted a typical Tzotzil home agricultural field where the children could sow maize and beans and take care of lambs, solve simple arithmetic problems and sell their products at a little store; and some Tangram puzzles in the E-toys language that develop arithmetic knowledge. Of these, "raining letters" was heavily used. The others were finished late in the school year and had less use. Table 2 summarized these activities.

When the instructor led activities within the classroom, the activity most frequently used (from observation and journal records automatically stored on each machine) was Write, because of its usability in different subjects. 
Table 2. Sugar activity uses

\begin{tabular}{|c|c|c|}
\hline Classroom moment & Sugar activity & Skills \\
\hline \multirow{5}{*}{$\begin{array}{l}\text { Teacher conducting the Span- } \\
\text { ish, Math or Science class }\end{array}$} & Write & $\begin{array}{l}\text { Punctuation marks, } \\
\text { Copy and record dictation on } \\
\text { the screen }\end{array}$ \\
\hline & Talking to Sarah & $\begin{array}{l}\text { Identify the sound and written } \\
\text { form of Spanish words } \\
\text { Listening comprehension }\end{array}$ \\
\hline & & Writing skills \\
\hline & Story Writer & To compose little stories \\
\hline & Calculator & $\begin{array}{l}\text { Solve math problems on the } \\
\text { screen }\end{array}$ \\
\hline \multirow{4}{*}{ Student exploring the software } & $\begin{array}{l}\text { Record (photographs, video or } \\
\text { audio) }\end{array}$ & $\begin{array}{l}\text { Illustrate a basic text with pic- } \\
\text { tures or videos }\end{array}$ \\
\hline & Photography & Skills to take pictures or videos \\
\hline & Puzzles & $\begin{array}{l}\text { Spatial skills and pattern recog- } \\
\text { nition }\end{array}$ \\
\hline & Memory & Spatial skills, memory skills \\
\hline
\end{tabular}

In the Spanish class, the "Raining letters" activity was primarily used so students could identify the keys, the location of the letters, and other functions on the keyboard. Using the Write activity students worked on exercises regarding the alphabet, punctuation marks, copy and record dictation on the screen and on the blackboard. It was also used to reinforce the topics covered in the class. The functional use of Spanish as a second language was fully reinforced by these activities in the computer.

In the field of Natural Sciences, students prepared reports incorporating photographs and videos that they had taken from plants and animals in the surrounding forest.

Other activities that were used include Story Writer, where the instructor shows pictures, and children describe them and create their own stories. The activity of Talking to Sara led to an improvement in pronunciation and in writing numbers in Spanish and an increase in vocabulary. In this activity, Sara, a figure on the screen, repeats out loud what the student writes, and it can also chat with the student.

The activities of Photography, Puzzles and Memory were the most explored by the students spontaneously, as they present very dynamic and creative exercises that eventually lead to the development of children's skills such as synthesis, analysis, autonomy, and collaboration.

Class observation made evident that the use of the computer in the classroom led to enthusiastic students whose interest in school subjects and collaboration with other pupils grew. Feedback and interaction became natural, as children's understanding of school themes and the computer software increased. These findings match the results obtained in the evaluation of the OLPC program in Peru (Santiago et.al., 2010) and Uruguay (Flores \& Hourcade, 2009). 
The impact on student learning is clear because they lost their shyness as the school year progressed and became more confident in themselves and in how they handled computers.

If the students hadn't had netbooks, many of the abilities in Spanish reading and writing, preparing reports and analyzing problems, and use of technology would have been difficult to develop in the traditional lecture format. At the beginning of the school cycle we noticed that the children were very shy and had a lack of confidence. They had a lot of difficulties in Spanish reading and writing, and in solving math problems. Gradually, as they worked with the computers they became more collaborative, more confident, and more interested in class content and developed the cognitive and technological abilities that we have mentioned.

Unfortunately, the tests usually used to measure cognitive abilities such as the BADIG (Yuste, 2006) are written with Spanish vocabulary more appropriate to urban children. Using these tests with indigenous, rural children would have been inappropriate, as these tests use terminology such as "refrigerator", which is unknown in most Tzotzil homes and exceeds the language and the conceptual knowledge of these children. Therefore the researchers only observed the growing cognitive capacities of the students in the classroom.

\section{Community Instructors}

Community instructors of both schools (Tilil and Naxoch) said they received two months of good quality initial training from CONAFE. When questioning them regarding such training, they indicated that the aspect they found most useful was the pedagogical. They also noted that they required more support to improve their teaching performance in developing their technological background and felt that linguistic, pedagogical, and cultural aspects were secondary to this.

The observations within the classroom enabled us to generally describe the teaching style of each instructor.

\section{Naxoch instructor}

The Naxoch instructor denoted authority in his voice. He spoke clearly and slowly. He usually started his lessons in Spanish; but when the students had comprehension difficulties, he switched to the Tzotzil language. His performance in the classroom reflected a sense of security and group control. He had a cordial and respectful attitude with his students and his face usually denoted seriousness. His dressing style was somewhat formal, wearing dress shoes, pants, and dress shirt, which was not consistent with children's clothing, or with other instructors' clothing. He dressed formally, in a Westernized style.

He answered student questions directly and personally. Since he sought control of the class, sometimes the atmosphere was quite rigid, limiting student exploration. Class planning was an important aspect of his teaching. He had the same kind of Classmate netbook as the children, which aided his teaching duties and lesson planning. The blackboard was a learning tool that he used frequently. On it he wrote word problems, paragraphs of text and made notes of his explanations.

This was the first teaching position for the instructors at both schools. They lacked pedagogical skills and experience; therefore at the beginning of the year, their class was rather disorganized and students did not pay much attention to explanations.

As time progressed, the Naxoch instructor improved his class handling and his teaching. He used the computer to plan class and to elaborate exercises for the students that he later distributed to the pupils through the computer network.

Figure 2 shows the instructor's main actions through the months of this project; the data is based on our field notes: 


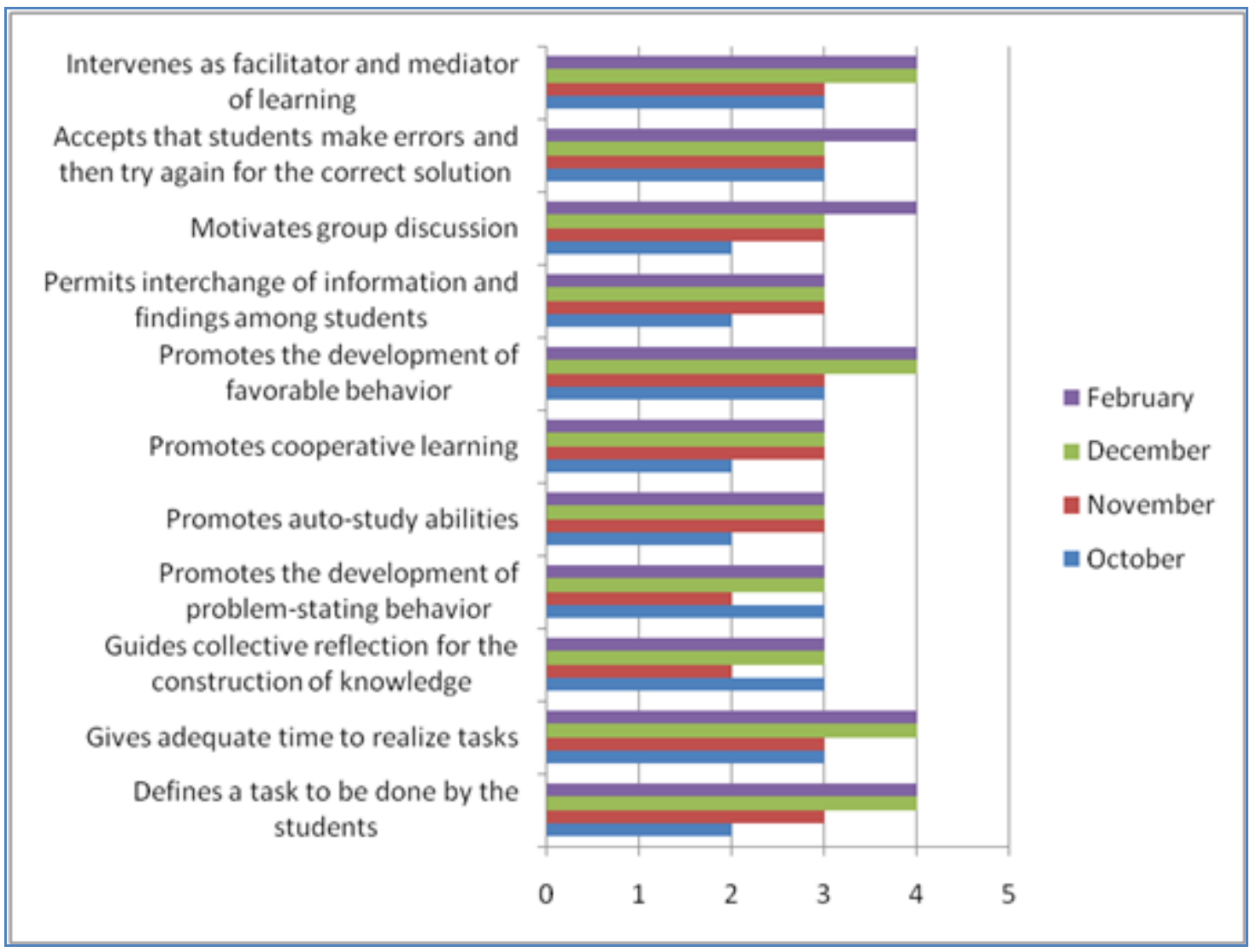

Figure 2. Development of teaching competencies of school instructor at Naxoch

Generally, new community instructors take several months to master their teaching abilities; in our project the improvement was much faster, likely due to the technological tools available that simplified class planning and many teaching tasks (Espinoza, 2009).

\section{Tilil instructors}

Community Instructor "A" at Tilil School initially denoted some nervousness and anxiety in her performance, which she compensated with a nice attitude, attentiveness, and friendliness with the students. Her dressing style was casual, comprising jeans, sneakers, and a sweater. In one of the first interviews she seemed to be distracted, did not comment much on her experience, and let instructor "B" dominate the discussion. As the school year progressed, she became more participatory, motivated, and interested in both the management of the group and of the computer and software.

Instructor "B" at Tilil showed more self-confidence and empathy. She also wore jeans, sneakers, and a casual jacket. Her face and gestures were very expressive which helped her address pupil's questions with ease. She was generally ordered, attentive, and participatory. The two instructors made up a good facilitating team when working in class with the computers. Each assumed her role according to her aptitudes and abilities. It is clear that they shared the responsibilities for the group and complemented each other very well.

Their teaching improved over time. When the school year started they had no control of the group; students did not follow instructions and there was a clear lack of class planning. With time the situation improved a lot. The classroom observations showed they planned, controlled the 
group better, established collaborative learning activities, and in many cases followed some of the lesson plans we had provided with the computers. All this helped to improve their organization and we observed a substantial improvement in the discipline and learning of these children.

They designed their own learning activities using the computers and collaborative learning. In one of these activities related to static electricity, they had children take photographs and incorporate them to their experiment report where they wrote collaboratively in their netbooks. In another activity, they had the students develop a weekly schedule using a table in the Write activity.

Figure 3 shows the development of teaching skills of instructors at Tilil School.

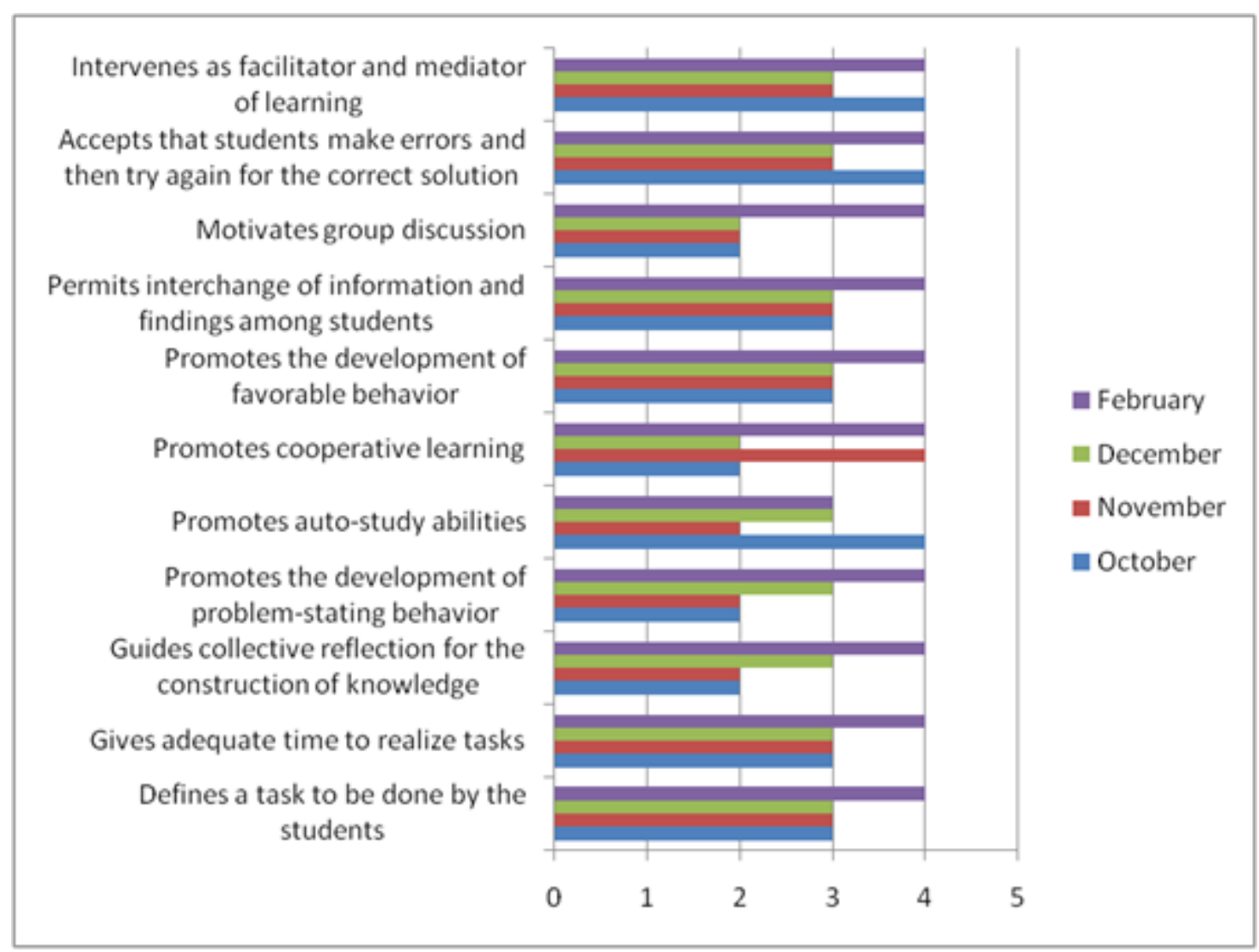

Figure 3. Teaching skills of the instructors of the school Tilil

The researchers were pleasantly surprised to discover how much students' parents were involved with the community school. They initially authorized the use of the computers and made frequent visits to find out how things were going (Espinoza, 2009)

The ability of instructors to use the computer in the classroom was the result of the pedagogical and technological training, as well as supervision on the behalf of the researchers. Just as in the Mexican urban schools (Cervantes et. al., 2011), infrastructural capacity, more than the technology itself, predicts the success of these experiences. 


\section{Conclusions}

\section{Main Findings}

As it has been shown, the implementation of the one-to-one model of educational technology and the constructionism methodology can make a difference in this special learning environment in which students and community instructors have little previous contact with computers.

Students got an enriched learning environment with learning activities and stimulus that led to an improvement in their oral and written Spanish as a second language. Their cognitive and technological skills showed great improvements in computer use, multimedia report development, solving collaborative exercises with the computer, elementary programming skills, and others.

Undoubtedly, the interest and motivation of the students increased considerably by having their own computer to play and learn with.

Furthermore, the technology facilitates the instructor's practice, as the classroom becomes a space for collaboration between students as assistants of each other for technological aspects and others related to the school subjects; thus freeing up instructor's time.

This model helped community instructors design their own class plans, gain confidence in the computers and their teaching, and to develop their teaching abilities with technology (Espinoza, 2009).

This research involved educational authorities and parents in order to support this experience. Other community instructors of Los Altos zone were interested in using computers in their schools; unfortunately the resources available were only sufficient for the two schools that were involved in the project.

This research allows us to recommend the following when implementing a "One to one constructionist" learning environment in indigenous communities:

- Involvement of all the educational actors (parents, students, educational authorities and teachers)

- Using the minimum equipment for setting up power; rugged and special mobile computers for children; a charging station (when the computers stay at school); a computer for the teacher that works also as a server for the other computers; enabling automatic backups of children's activities; internet connection if available; furniture suited to this environment.

- Lesson plans and digital curriculum adjusted to the use of technology

- Teacher training in the use of technology and constructionist pedagogy

- Accompanying teachers until they become autonomous in the design of their own learning environment and activities using the computer.

- The Sugar Learning Environment because of all its constructionist activities, its children orientation and the communication and screen-sharing that Sugar enables between students

In this project the researchers managed to combine all these aspects. The most important finding was that the use of technological tools in the classroom enhances the interest and motivation of both students and their teachers and allows the development of thinking skills by students, as well as providing them with enhanced technological skills. 


\section{Recommendations for Future Similar Projects}

The Mexican and CONAFE curriculums were designed without any consideration of the use of technology; these are so long that generally professors and community instructors are very pressed to teach all assigned themes. Therefore, there is little time and opportunity to introduce new activities based on technology. The researchers recommend the careful consideration of the way the existing activities can be enriched with the use of technology, rather than inventing totally new activities.

We recommend designing self-learning training tutorials, so that future instructors can learn by themselves about the constructionist pedagogy and the use of the one-to-one technology including Sugar, the learning activities, and the example lesson plans that the researchers prepared.

Cognitive tests adequate for indigenous, rural children are necessary so the improvements in the use of the technology and methodology can be better evaluated.

The researchers were unable to obtain further funding to continue their visits after the project ended; they heard the computers continued to be used by the new instructors and children, but do not know how often or how effectively. We hope these children, with their increased cognitive abilities and handling of technology will in the future become involved in the development of their communities.

Of course it is necessary to conduct more research in Mexico and Latin America to establish the best way to implement technology-based participatory learning for indigenous children.

\section{Acknowledgements}

We heartfully thank the John D. and Catherine T. MacArthur Foundation and HASTAC for this opportunity to contribute to the development of our indigenous children. This paper improved considerably after considering the careful review of Lynn Jeffrey, one of this journal's editors.

\section{References}

Alberta Education. (2006). One-to-One mobile computing: Literature review. Retrieved 29 September 2009 from the ERIC database at http://www.eric.ed.gov/

Alberta Education. (2009). Emerge, One-to-One Laptop Initiative: Year one report. Retrieved 29 September 2009 from the ERIC database at http://www.eric.ed.gov/

Badilla, E., \& Chacón, A. (2004). Construccionismo: Objetos para pensar, entidades públicas y micromundos [Objects for thinking, pubic entites and microworlds] Revista Electrónica Actividades Educativas en Investigación, 4(001). Retrieved 25 September 2009 from http://redalyc.uaemex.mx/redalyc/src/inicio/ArtPdfRed.jsp?iCve=44740104

Bass, R, \& Schlafly, T. (2009). Participatory learning and the new humanities: An interview with Cathy Davidson. In blog Academic Commons, January 7 2009. Accessed July 2012 from http://academiccommons.org/commons/essay/participatory-learning-and-new-humanities-interviewcathy-davidson

Cantú, F., \& Heredia, Y. (2010). A model for e-learning and knowledge management: The virtual university at Tecnológico de Monterrey. In J. Liebowitz \& P. Frank (Eds.), Knowledge management and elearning. Maryland, EEUU: Taylor \& Francis Group.

Cervantes, R., Warschauer, M., Nardi, B. \& Sambasivan, N. (2011). Infrastructure for low-cost laptop use in Mexican Schools. Proceedings of the Conference on Human-Computer Interaction CHI 2011, Vancouver, Canada, pp 945-954.

Coll, C., \& Monereo, C. (2008). Psicología de la educación virtual [Psychology of virtual education] (pp. 19-51). Madrid: Ediciones Morata. 


\section{Technology-based Participatory Learning}

Consejo Nacional de Fomento Educativo CONAFE. (2006). Equidad y calidad en la educación básica. [Equity and qulaity in basic education]. México: Seretaría de Educación Pública.

Consejo Nacional de Fomento Educativo, CONAFE (2007). Marco conceptual.[Conceptual framework] Retrieved 21 September 2009 from http://www.conafe.gob.mx/gxpsites

Consejo Nacional de Fomento Educativo, CONAFE. (2009). Educación comunitaria. [Communitarian education] Retrieved 29 August 2009 from http://www.conafe.gob.mx

Coronel, A. (2008). Perfil de los Instructores Comunitarios del CONAFE, Zona de operación San Cristóbal de las Casas, Chiapas[Profile of communitarian instructors of CONAFE, operation zone of San Cristóbal de las Casas, Chiapas] Unpublished master's thesis. Escuela de Graduados en Educacion, Universidad TecVirtual, México

Espinoza, R. (2009). Acercamiento al enfoque pedagógico construccionista en un contexto educativo vulnerable. Una muestra de casos-tipo. [Approach to the constructionist pedagogy in a vulnerable educational context]. Unpublished master's thesis. Escuela de Graduados en Educación, Universidad TecVirtual, México

Falbel, A. (2001) Construccionismo. [Constructionism]. Retrieved 21 September 2009 from http://llk.media.mit.edu/projects/panama/lecturas/Falbel-Const.pdf

Flores, P., \& Hourcade, J. P. (2009). One year of experiences with XO Laptops in Uruguay. Interactions, July-August, 52-55. Available in ACM digital library.

Hourcade, J. P., Bitler, D., Comerzana, F., \& Flores, P. (2008). Early OLPC experiences in a rural Uruguayan school. Proceedings of the Conference on Human-Computer Interaction CHI 2008, Florence, Italy, pp.2503-2511

Icaza, J. I. (2008). Constructionism in five easy steps. Retrieved June 2012 from http://joseiknols.wordpress.com/article/constructionism-in-5-easy-steps-1i3jm1s12rl3d-5/

Instituto Nacional de Estadística y Geografía INEGI. (2012). Anuario Estadístico de Chiapas, 2012. [Yearly statistical summary of Chiapas, 2012]. Retrieved June 12 from http://www.inegi.org.mx/est/contenidos/espanol/sistemas/sisnav/default.aspx?proy=aee\&edi=2008\&en $\underline{\mathrm{t}=07}$

Mortera, F. (2008). El aprendizaje hibrido o combinado (blended learnig), acompañamiento en las aulas del siglo XXI. [Hybrid or combined learning (blended learning) for XXI century classrooms] In A. Lozano \& V. Burgos (Eds.), Tecnología Educativa en un modelo de educación a distancia centrado en la persona. pp. 125-156. México: Limusa.

Obregon, M. (2003). Tzotziles. México. Comisión Nacional para el Desarrollo de los Pueblos Indígenas. Retrieved June 2007 from http://www.cdi.gob.mx/index.php?option=com_docman\&task=doc_download\&gid=57\&Itemid=24\&e $\mathrm{i}=$ NyjRT4G5CafM2gWwtNGnDw\&usg=AFQjCNE4Pw_giRVPW4x2tO1ILb0gWnDQDw\&sig2=59jI rJ-ZNOA9qN_WyjHj7Q; or else Google [tzotziles site:cdi.gob.mx] accessed June 2007.

One Laptop Per Child [OLPC]. (2008). One Laptop Per Child. Retrieved February, 10 from http://es.wikipedia.org/wiki/OLPC

Papert, S. (1993). Mindstorms: Children, computers, and powerful ideas. New York: Basic Books.

Papert, S. \& Harel, I. (1991). Situating constructionism. Retrieved 21 September 2009 from http://www.papert.org/articles/SituatingConstructionism.html

Penuel, W. (2004). Implementation and effects of one-to-one computing initiatives: A research initiative. Retrieved 29 September 2009 from the ERIC database (EJ728908).

Santiago, A., Severin, E., Cristia, J., Ibarrarán, P., Thompson, J., \& Cueto, S. (2010). Evaluacion experimental del programa "Una laptop por niño" en Perú. [Experimental evaluation of the One Laptop Per Child program in Perú] Aportes, 5(June), 1-12. Banco Interamericano de Desarrollo, Washington D.C. USA. 
Secretaria de Educación Pública [SEP]. (2012). Sistema Educativo de los Estados Unidos Mexicanos. Principales cifras, ciclo escolar 2009-2010. [Educational system of Mexico. Main indicators, school cycle 2010-2011]. Retrieved May 2012 http://www.dgpp.sep.gob.mx/pricipalescifras/

Secretaría de Hacienda y Crédito Público (2010). Enciclopedia de los municipios y delegaciones de México. Chiapas: indice y grado de marginación. [Encyclopedia of municipalities and delegations of Mexico. Chiapas: indicators and degree of marginality]. Secretaría de Hacienda y Crédito Público, subsecretaría de Planeación y Evaluación. Retrieved June 2012 from http://www.elocal.gob.mx/work/templates/enciclo/EMM07chiapas/AE03 conapo.html

Sistema Estatal de Información Estadística y Geográfica de Chiapas, SEIEG. (2007). Prontuario estadístico 2007. [Statistical compendium 2007]. Retrieved 30 August 2009 from http://www.chiapas.gob.mx/mapas/

SugarLabs. (2009a). Sugar Labs/Current events. Retrieved 1 September 2009 from http://wiki.sugarlabs.org/go/Sugar_Labs/Current_Events

SugarLabs. (2009b). Gardner Pilot Academy. Retrieved 1 September 2009 from http://wiki.sugarlabs.org/go/Gardner_Pilot_Academy

SugarLabs (2009c). Do children want to learn with Sugar? Retrieved 1 September 2009 from http://www.olpcnews.com/software/sugar/children_want_to_learn_with_sugar.html

SugarLabs (2009d). Sugar on Classmate PC: Education owned by open source. Retrieved 1 September 2009 from http://www.olpcnews.com/software/operating_system/sugar_on_classmate_pc.html

SugarLabs (2009e). Sugar learning platform status - Post OLPC. Retrieved 1 September 2009 from http://www.olpcnews.com/software/sugar/sugar_learning_platform_status.html

SugarLabs (2010). Sugar Labs. Retrieved April 2010 from http://www.sugarlabs.org

Torres, R., \& Tenti, E. (2000). Políticas educativas y equidad en México: La experiencia de la educación comunitaria, telesecundaria y los programas compensatorios. [Educational politics and equity in Mexico: experiences from communitarian education, tele-secondary school and compensational programs] Retrieved 21 September 2009 from http://www.lpp-uerj.net/olped/documentos/1050.pdf

Warschauer, M., Cotten, S., \& Ames, M. (2011). One Laptop Per Child Birmingham: Case study of a radical experiment. International Journal of Learning and Media, 3(2), 61-76.

Yuste, C. (2006). BADIG: Batería de aptitudes diferenciales y generales. [Compendium of tests about differential and general aptitudes]. CEP Editorial:Madrid

\section{Biographies}

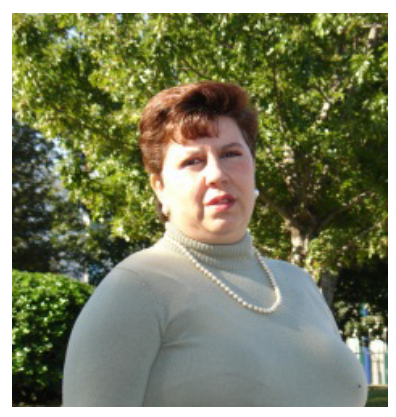

Dr. Yolanda Heredia Escorza received her Bachelor's Degree in Psychology with specialty in clinical Psychology from the Universidad Iberoamericana in México City in 1982; her Master's Degree in Education with a specialization in Educational Psychology from the Universidad Regiomontana in 1992; and her Ph D. in Social Work with a specialization in International Comparative Social Welfare Policy in a joint degree from Universidad Autónoma de Nuevo León and UTA in 2002.

Currently she is a Senior Professor and Researcher at the Graduate School of Education, Universidad TecVirtual of Sistema Tecnológico de Monterrey; and coordinates the Master's in Educational Technology and the PhD in Educational Innovation. She was dean of the Graduate School of Education from January of 2009 to August of 2010. She has done research in educational technology and in the subject of elements that affect academic performance, and she has published the results of her research in specialized magazines and has written several chapters in books. She has coordinated 25 thesis and 8 dissertations. 


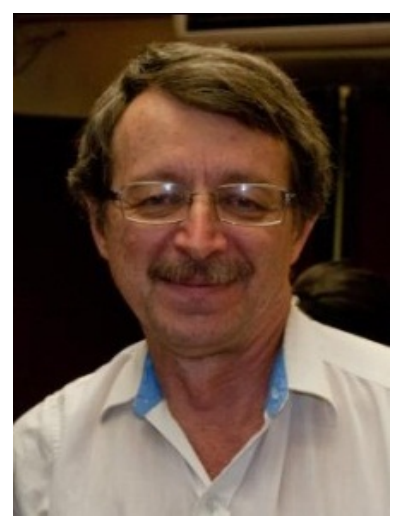

Dr. Jose Ignacio Icaza studied Electro-mechanical engineering at the Universidad Iberoamericana of Mexico city. He received his Msc. in Computer Science at the University of Southern California and his $\mathrm{Ph}$.D. in Computer Science at the University of Waterloo, Canada. He has lead engineering, business, and systems software development projects in Mexico, England, Canada and the US, and was a researcher at Mexico's Instituto de Investigaciones Eléctricas and the Universidad Autónoma Metropolitana before joining Tecnológico de Monterrey in 1987, where he managed the Center for Research on Educational Technology. Currently he is an associate professor at the Computer Science department. His current research interests include on-line learning environments and virtual work-team collaboration. He is the author of several publications in on-line learning environments and strategies. 